\title{
ANALYSIS OF THE PROBLEM OF STAFF ALLOCATION TO WORK STATIONS
}

doi: 10.2478/cqpi-2019-0073

Date of submission of the article to the Editor: 18/04/2019

Date of acceptance of the article by the Editor: $30 / 05 / 2019$

Marek Krynke ${ }^{1}$ - orcid id: 0000-0003-4417-1955

Krzysztof Mielczarek ${ }^{1}$ - orcid id: 0000-0003-3701-0192

Alan Vaško ${ }^{2}$ - orcid id: 0000-0002-3937-2691

${ }^{1}$ Czestochowa University of Technology, Poland

2University of Žilina, Slovakia

\begin{abstract}
The proper organization of work is to set the workflow to the slightest effort of man and machine operation to obtain maximum results. The article presents the problem of the allocation of personnel that occurs in a real company. The mathematical model for this issue was formulated. An algorithm solving the problem of personnel allocation is presented. The proposed analysis is a starting point for determining the production capacity and load of each workstation, which is particularly important when using multi-station work and balancing the production line.
\end{abstract}

Keywords: work organization, multi-station work, linear programming

\section{INTRODUCTION}

The main production factors are labor resources, work items and human work, their interdependence in the production process has a decisive impact on the efficiency and effectiveness of the entire production system. This is especially important when used in the production of multi-station work, where the human work and workstation must be adapted in a suitable way (Grzelczak, 2018).

For human work to be effective, it should be properly organized. Proper organization of work consists in setting the workflow so that, with the least amount of work and technical means, and the least time wasted, maximum results can be obtained. Badly organized work leads to unnecessary consumption of production means and human work, without bringing economic effects commensurate with the incurred outlays, and also without creating optimal conditions for the working person, which should translate into the humanization of work (Klimek and Łebkowski, 2011).

The organization of work is the sum of technical, economic and organizational activities aimed at designing the optimal combination of human work and means of production (objects and means of work) and ensuring proper working conditions for people.

\section{THE ISSUE OF ALLOCATION OF EMPLOYEES TO WORK POSITIONS}

The allocation of employees to workplaces is an important optimization issue, which consists in delegating employees to individual positions (tasks), in such a way that the 
cost of task completion is minimal or the total efficiency of all employees is maximal. The allocation should take into account the employee's characteristics, ie work efficiency, skills, experience, etc. The criterion for assessing such an assignment is, for example, achieving maximum personnel performance or filling all jobs taking into account the employees' qualifications and skills (Knop, 2015).

The issue of employee allocation to posts is presented as a two-dimensional graph (Fig. 1 ), in which its disjoint parts are a set containing nodes representing employees and a set containing nodes representing positions (Kozioł-Kaczorek and Pietrych, 2016). There are weighted connections between employees and positions. The weights of employees' connections with positions determine the productivity or cost of an employee when performing tasks in a given position (Krynke and Mielczarek, 2018).

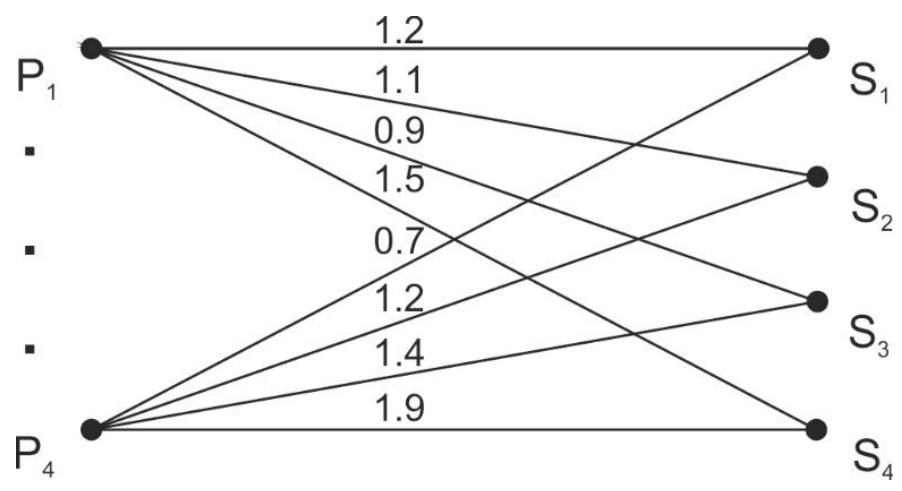

Fig. 1. The bipartite graph for the problem of allocation $n=4$ employees $P$ to $m=4$ positions $S$

The mathematical model of the classical allocation problem can be presented as the problem of minimizing the $F_{c}(1)$ or cost function or maximizing the $F_{w}(2)$ performance function:

$$
\begin{gathered}
F_{c}=\sum_{i=1}^{n} \sum_{j=1}^{m} c_{i j} \cdot x_{i j} \rightarrow \min \\
F_{w}=\sum_{i=1}^{n} \sum_{j=1}^{m} w_{i j} \cdot x_{i j} \rightarrow \max
\end{gathered}
$$

Where:

$x_{i j}$ - decision variable, zero-one value, indicating the allocation or lack of allocation of the $i^{\text {th }}$ employee to the $f^{\text {th }}$ position,

$c_{i j}$ - the unit labor cost of the $i^{\text {th }}$ employee at the $j^{\text {th }}$ position,

$w_{i j}$ - unitary work of the $i^{\text {th }}$ employee's job at the $j^{\text {th }}$ position,

$n$ - number of employees,

$m$ - number of work positions.

\section{RESEARCH PROBLEM}

A certain architectural office must plan its monthly activity in order to get the most profit. There are currently 4 orders available:

- Z1 - projects of single-family houses - permanent order,

- Z2 - design of a production and office building - one-time order, which must be completed in the nearest month, 
- Z3 - design of a car dealership - one-time order, completion date for 3 months. To get the job done on time assumed that in each of the first two months will be made at least $40 \%$ of the entire project,

- Z4 - - bridge design - a one-time order, must be completed in the next month. To describe a given situation with a mathematical model, one should find a way to characterize tasks using numbers. Important parameters are the employee's salary and the time needed to perform a specific task (Table 1).

Table 1

Number of work units required for a given order and remuneration per unit of work for a given order

\begin{tabular}{|c|c|c|c|c|}
\hline & Z1 & Z2 & Z3 & Z4 \\
\hline number of service hours [h] & optional & 200 & $\begin{array}{c}150(40 \% \text { of the } \\
\text { total order })\end{array}$ & 50 \\
\hline $\begin{array}{c}\text { gross income per } \\
\text { man-hour [PLN] }\end{array}$ & 40 & 50 & 60 & 120 \\
\hline
\end{tabular}

Source: own study

Five employees work in the company. Their characteristics are presented in Table 2.

Table 2

Working time and skills of employees

\begin{tabular}{|l|l|}
\hline Anna & $\begin{array}{l}\text { A beginner designer, fluent in software support, experience in single-family } \\
\text { house designs. Full time employed (140h). }\end{array}$ \\
\hline Beata & $\begin{array}{l}\text { Designer, experience in single-family house designs. } \\
\text { Full time employed (140h) }\end{array}$ \\
\hline Cezary & $\begin{array}{l}\text { Designer, experience in various projects. } \\
\text { Part-time employee (70h), overtime if necessary. }\end{array}$ \\
\hline Daniel & $\begin{array}{l}\text { A specialist in the bridges design. } \\
\text { A contracted employee, if necessary, is ready to take overtime. }\end{array}$ \\
\hline Eugeniusz & $\begin{array}{l}\text { Designer with long experience. A great sense of engineering. } \\
\text { Part-time employee (70h), overtime if necessary. }\end{array}$ \\
\hline
\end{tabular}

Source: own study

The working time and remuneration of employees can be clearly described numerically. The more difficult issue is the assessment of work efficiency. The solution to this problem is to determine the effectiveness coefficients of a given employee working on a given task. Table 3 presents the preference matrix and employee remuneration.

Table 3

Employee preference matrix for particular tasks

\begin{tabular}{|c|c|c|c|c|c|}
\hline & Anna & Beata & Cezary & Daniel & $\begin{array}{c}\text { Eugenius } \\
\mathbf{z}\end{array}$ \\
\hline Working time [h] & 140 & 140 & $>70$ & $>0$ & $>70$ \\
\hline $\begin{array}{c}\text { Salary per man-hour } \\
{[\mathrm{PLN}]}\end{array}$ & 20 & 25 & 65 & 80 & 40 \\
\hline
\end{tabular}




\begin{tabular}{|c|c|c|c|c|c|}
\hline $\mathrm{z}_{1}$ & 1,2 & 1,3 & 1,2 & 1,1 & 1,2 \\
\hline $\mathrm{z}_{2}$ & 0,8 & 1 & 1,1 & 1,1 & 1,3 \\
\hline $\mathrm{z}_{3}$ & 0,8 & 0,9 & 1 & 1,2 & 1,3 \\
\hline $\mathrm{Z}_{4}$ & 0,5 & 0,7 & 0,5 & 1,5 & 0,9 \\
\hline
\end{tabular}

Source: own study

The monthly total profit of the realization of the project orders are described as:

$$
\begin{aligned}
F & =h_{11} \cdot\left(z_{11} r_{1}-w_{1}\right)+h_{21} \cdot\left(z_{21} r_{2}-w_{1}\right)+h_{31} \cdot\left(z_{31} r_{3}-w_{1}\right)+h_{41} \cdot\left(z_{41} r_{4}-w_{1}\right) \\
& +h_{12} \cdot\left(z_{1 F 2} r_{1}-w_{2}\right)+h_{22} \cdot\left(z_{22} r_{2}-w_{2}\right)+h_{32} \cdot\left(z_{32} r_{3}-w_{2}\right)+h_{42} \cdot\left(z_{42} r_{4}-w_{2}\right) \\
& +h_{13} \cdot\left(z_{13} r_{1}-w_{3}\right)+h_{23} \cdot\left(z_{23} r_{2}-w_{3}\right)+h_{33} \cdot\left(z_{33} r_{3}-w_{3}\right)+h_{43} \cdot\left(z_{43} r_{4}-w_{3}\right) \\
& +h_{14} \cdot\left(z_{14} r_{1}-w_{4}\right)+h_{24} \cdot\left(z_{24} r_{2}-w_{4}\right)+h_{34} \cdot\left(z_{34} r_{3}-w_{4}\right)+h_{44} \cdot\left(z_{44} r_{4}-w_{4}\right) \\
& +h_{15} \cdot\left(z_{15} r_{1}-w_{5}\right)+h_{25} \cdot\left(z_{25} r_{2}-w_{5}\right)+h_{35} \cdot\left(z_{35} r_{3}-w_{5}\right)+h_{45} \cdot\left(z_{45} r_{4}-w_{5}\right)
\end{aligned}
$$

where:

$h_{j i}$ - number of possible employee's working hours $i$ for task $j$,

$z_{j i}-$ employee performance coefficient $i$ performing task $j$,

$r_{j}$ - cost of man-hour for task $j$,

$w_{i}$ - salary for an employee $i$.

It is a function that should be maximized. At the same time, the available standard hours of work:

$$
\begin{aligned}
& h_{11}+h_{21}+h_{31}+h_{41}=140 \\
& h_{11}+h_{21}+h_{31}+h_{41}=140 \\
& h_{13}+h_{23}+h_{33}+h_{43}>70 \\
& h_{14}+h_{24}+h_{34}+h_{44}>0 \\
& h_{15}+h_{25}+h_{35}+h_{45}>70 \\
& h_{13}+h_{24}+h_{34}+h_{43}<140 \\
& h_{14}+h_{24}+h_{34}+h_{44}<140 \\
& h_{15}+h_{25}+h_{35}+h_{45}<140
\end{aligned}
$$

and requirement concerning production order - limitations of work units:

$$
\begin{aligned}
& h_{11} a_{11}+h_{12} a_{12}+h_{13} a_{13}+h_{14} a_{14} \geq 0 \\
& h_{21} a_{21}+h_{22} a_{22}+h_{23} a_{23}+h_{24} a_{24}=200 \\
& h_{31} a_{31}+h_{32} a_{32}+h_{33} a_{33}+h_{34} a_{34} \geq 150 \\
& h_{31} a_{31}+h_{32} a_{32}+h_{33} a_{33}+h_{34} a_{34} \leq 375 \\
& h_{41} a_{41}+h_{42} a_{42}+h_{43} a_{43}+h_{44} a_{44}=50
\end{aligned}
$$

Defined task is possible to be solved in the environment Octave. Octave is a free programme for numerical calculations (mathematical and engineering calculations). This language is intuitive and friendly (for a mathematician) (Nagar, 2018). With basic functionality in Octave there are operations on matrices and number of numerical methods solving linear and non-linear problems. Octave is software featuring a highlevel programming language, primarily intended for numerical computations. Octave helps in solving linear and nonlinear problems numerically, and it is used for performing other numerical experiments with the use of a language that is mostly compatible with MATLAB.

The issue of assigning employees to particular tasks was solved using the glpk command. The GNU Linear Programming Kit (GLPK) is a software package intended for solving large-scale linear programming (LP), mixed integer programming (MIP), and other related problems (Piechna, 2012). 
GLPK uses the revised simplex method and the primal-dual interior point method for non-integer problems and the branch-and-bound algorithm together with Gomory's mixed integer cuts for (mixed) integer problems.

\section{ANALYSIS OF THE RESULTS}

After doing calculations, the optimal values of working hours of individual employees was obtained. In Fig. 2 optimal assigning project tasks to employees was described. For a planned process, realization of the project $Z 1$ will be the most effective only by Anna with a little help from Beata, realization of the project $Z 2$ by Beata and Cezary, realization of the project $Z 3$ will be the most effective by Eugeniusz with a help from Cezary. In turn, realization of the project Z4 will be the most effective only by Daniel.

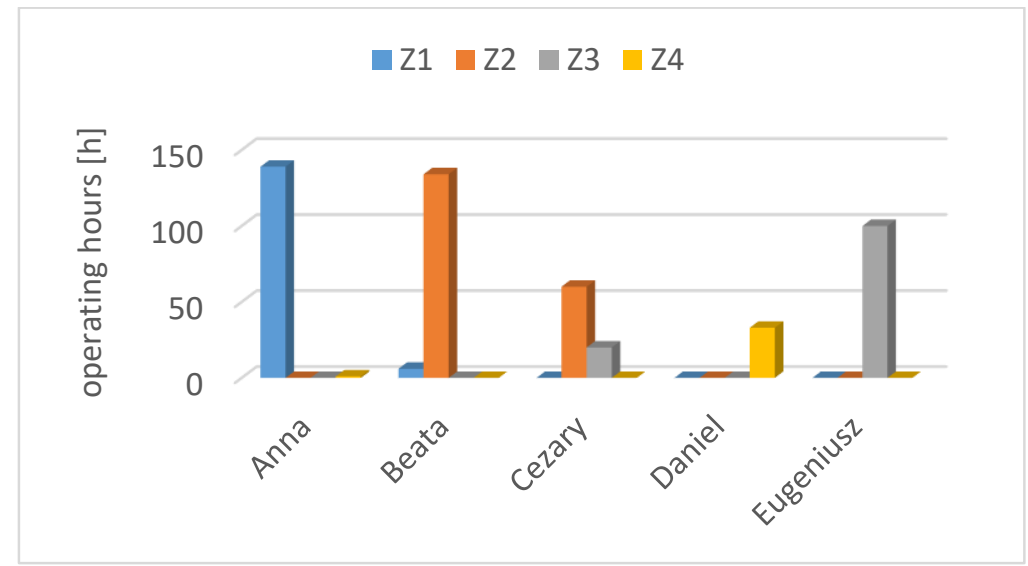

Fig. 2. Optimal assigning tasks to individual employees

In Fig. 3 the use of the time fund by individual employees the background of available standard hours of work was presented. It can be seen that in order to execute the entrusted tasks, Cezary and Eugeniusz have to work overtime. In Fig. 4 the profit generated by the individual employees was presented. An interesting situation occurred in the case of Cezary. As a highly qualified employee, it has relatively high pay. So much that the execution of such tasks entrusted to him bring loss.

working time fund overworked time

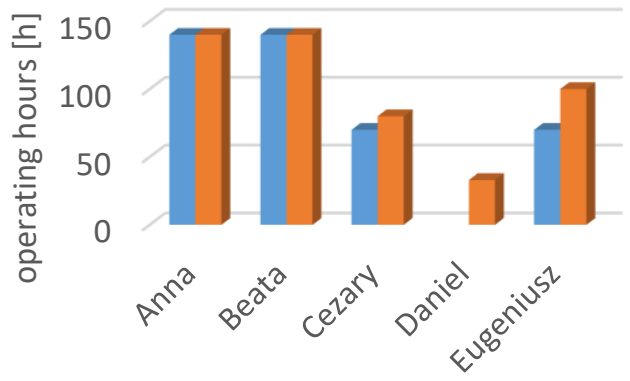

Fig. 3. The use of the time fund by individual employees profit generated by the employee

salary

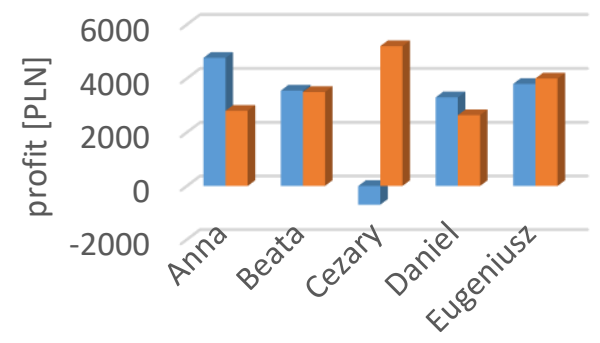

Fig. 4. Profit generated by the individual employees

In Fig. 5 a graph that compares the total cost of the realization of the order program for two extreme cases was presented. The first situation concerns the optimal solution, 
when profits are subjected to the maximization. For comparison, the second one shows a situation when profits were minimized.

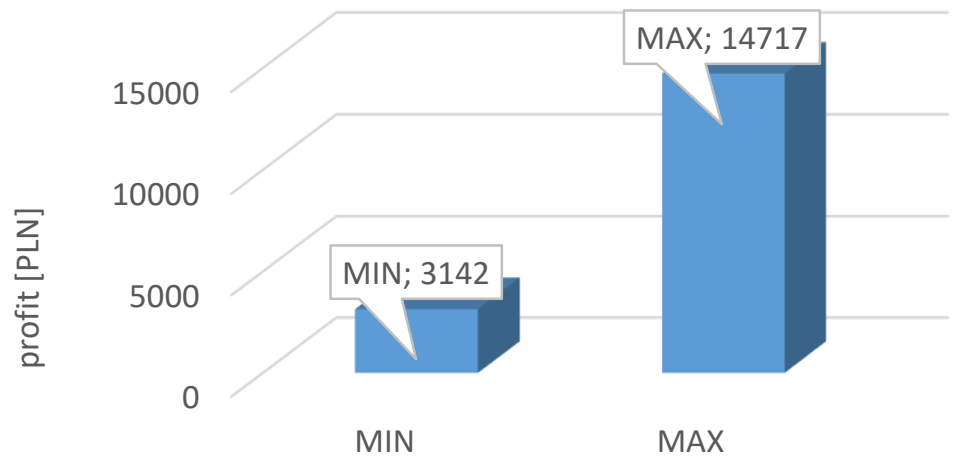

Fig. 5. Total profit of the realization of the order program in the case of the criterion of minimization and maximization

\section{CONCLUSION}

The normalization of work fulfils a fundamental role in both management of the whole enterprise and human work. It allows to calculate the length of production cycles, to determine the planned tasks of individual positions, to calculate the demand for employees, taking into account their skills and qualifications, to determine the needs of machinery and equipment, to calculate labor costs, determine work efficiency and its dynamics.

The above mathematical model and the method of its solution is applicable in many engineering problems, eg the problem of optimal use of resources, implementation of the cheapest order, etc.

The presented example can be analogously extended to a larger number of employees and tasks as well as months.

\section{REFERENCES}

Grzelczak, A., 2018. Norma czasu a zarządzanie produkcją w aspekcie pracy wielostanowiskowej, Innowacje w Zarządzaniu i Inżynierii Produkcji, Knosala R. (red.), Oficyna Wydawnicza Polskiego Towarzystwa Zarządzania Produkcją, 432440.

Klimek. M., Łebkowski, P., 2011. Algorytm dla problemu losowego przydziału personelu, Logistyka, 2, 299-306.

Knop, K., 2015. Statistical analysis of responses concerning the importance of human and production or services issues in various companies, Production Engineering Archives, 7, 40-44.

Kozioł-Kaczorek D., Pietrych Ł., 2016. Grafy a teoria stabilnych alokacji, Ekonometria Econometrics, 3(53), 102-114.

Krynke, M., Mielczarek, K., 2018. Applications of linear programming to optimize the cost-benefit criterion in production processes, MATEC Web of Conferences, Vol.183, 6s.

Nagar, S., 2018. Introduction to Octave: For Engineers and Scientists, Apress, NewYork.

Piechna, A., 2012. Zadanie programowania liniowego w środowisku GNU Octave, PiKI, $55,58-62$. 